\title{
The Relationship between the Role of Health Workers and Community Leaders with the Occurrence of Dengue Hemorrhagic Fever
}

\author{
Tesha Pertiwi ${ }^{1}$, Nurmaini ${ }^{2}$, Etti Sudaryati ${ }^{2}$ \\ ${ }^{1}$ Master Student in Faculty of Public Health, Universitas Sumatera Utara, Indonesia \\ ${ }^{2}$ Lecturer in Universitas Sumatera Utara, Indonesia \\ Email: teshapertiwi81@gmail.com
}

\begin{abstract}
:
Dengue Hemorrhagic Fever (DHF) is a disease caused by the dengue virus that attacks the human body. One factor that can be overcome by counseling to the community by health workers and community leaders. In 2018, Medan experienced an increase in DHF cases, that is as many as 1490 cases, and the death rate due to DHF was 13 people, this condition is still a health problem that must be dealt with immediately. This study aims to analyze the relationship between the health workers and community leaders with the occurrence of DHF. This type of research is descriptive, with cross-sectional design. The study population are all families in Medan, the study sample as many as 300 families which taken by using simple random sampling technique. The data collection tool uses a questionnaire. The results showed that the level of health workers in the prevention of DHF was in good criteria only 7.7 percent and the level of support of community leaders in preventing DHF was in good criteria only 9.7 percent. Bivariate analysis shows that there was no significant relationship between the health workers and community leaders with the occurrence of DHF in Medan. The role of health workers and community leaders was still lacking in efforts to prevent DHF. It is recommended that health workers and community leaders play an active role in providing counseling to the public about DHF.

Keywords:

health workers; community leaders; prevention of dengue hemorrhagic fever
\end{abstract}

\section{Introduction}

Infectious disease is a disease that is still a health problem in the community, plus Indonesia with its tropical climate will facilitate vectors of infectious diseases to proliferate, such as dengue hemorrhagic fever (DHF). Dengue hemorrhagic fever is a dangerous infectious disease, in which the transmission period is very fast, resulting in death due to bleeding.

DHF is one of the infectious disease that is very dangerous because in a short time can cause death. One of the main health problems in Indonesia is DHF, because this disease causes many casualties and attacks all regions in Indonesia both urban and rural. Dengue Hemorrhage Fever (DHF) is an infectious disease caused by Arthrophod Borne Virus, Family Flaviviridae, and Genus Flavivirus is an epidemic vector that is mainly spread by the bite of the Aedes aegepti mosquito but other species such as Ae. Albopictus, Ae. Polynesiensis, Ae. Scutelaris and Ae, Niveus are also considered as secondary vectors. In all corners of Indonesia there are dengue mosquitoes, except in areas with a height of more than 1000 meters above sea level. The causes of the increase and spread of dengue cases are very complex including population growth, the occurrence of uncontrolled and supervised urbanization, the absence of monitoring of disease vector development and the rapid development of transportation (Directorate General of P2P Ministry of Health, 2015). 
The first outbreak of dengue occurred in Frech West Indies (Caribbean Islands) in 1653. Dengue disease was first reported in Australia in 1897, then followed by Italy and Taiwan in 1931. In 1953 to 1954 in Philippines there was also an outbreak at that time Southeast Asian region including Indonesia received an attack of the disease followed by a fairly high mortality rate. The occurrence of DHF continues to increase in several countries in Southeast Asia and the area of such a very wide spread was felt for twenty years and then an increase in cases occurred over the next 20 years (Ginanjar, 2008). The occurrence of DHF in this world, especially in Asia, Latin America and Africa has been estimated over the past few years, and mathematical calculations show as many as 50 to 100 million symptoms of dengue cases that will occur (WHO, 2016).

In 2014 there was an increase in the number of DHF sufferers in Indonesia by 100,347 cases to 129,650 cases in 2015 . Data on the number of DHF sufferers increased to 201,885 cases (Ministry of Health, 2017). There were four provinces in 2016 with high dengue cases, namely East Java (340 cases), West Java (270 cases) Central Java (231 cases) and East Kalimantan (103 cases). The lowest number of cases was achieved by Papua (zero cases), NT'T and West Sulawesi (two cases) and the Pacific Islands (three cases). The lowest DHF case achievement was achieved by Papua Province (zero cases), NTT, West Sulawesi (two cases), and Bangka Belitung Islands (three cases). There are seven provinces in 2016 with IR above the risk for every 100,000 population or death cases in the top 100 provinces that are claimed are Bali (484), East Kalimantan (306), DKI Jakarta (198.7), Yogyakarta (167.9), North Kalimantan (158.3), Southeast Sulawesi (123.3) and South Kalimantan (101.1) and the lowest IRs are in Papua Province (11.8) and West Kalimantan (12.1) (Dirjen P2P Ministry of Health RI, 2015).

The occurrence of DHF in the Province of North Sumatra In January to November 2016 was quite high as many as 7,777 people of North Sumatra suffered from DHF and 48 people died, the CFR was equal to $0.62 \%$. Medan itself is in the top position with 3,010 cases and 17 people died during 2015 to 2016, followed by Deli Serdang District as many as 1,958 cases and 10 people died, and Simalungun District as many as 1,733 cases, 0 people died with CFR equal to $0.56 \%$. (IR) / morbidity rate in 2015, Sibolga was 163.6 patients first, followed by Tebing Tinggi as many as 125.3 patients and Binjai as many as 88.3 patients. While IR in 2016, Pak Pak Bharat Regency was 166.3 patients, Tebing Tinggi as many as 150.7 patients, and Samosir District as many as 130.0 sufferers.

In 2018, Medan experienced an increase in DHF cases, namely as many as 1490 cases, and the number of deaths due to DHF as many as 13 people, this condition is still a health problem that must be addressed immediately and sought a solution. This study aims to determine the description of the role of health workers and community leaders in the prevention of DHF (Medan City Health Office, 2018).

Public health behavior in the control and eradication of mosquito larvae is strongly influenced by the role of health workers, and the presence of community leaders gives a great influence for an individual on their health status, the encouragement from outside, role models will determine how someone behaves and behaves especially in efforts to prevent dengue.

The increase in dengue cases is actually caused by several factors including, mobility and uncontrolled urbanization flows, the quantity and quality of human resources managing DHF problems in every administrative area that is inadequate, inter-sectorial commitment is still low, especially in efforts to prevent dengue, the occurrence climate change which from time to time makes prevention efforts difficult to implement, coordination regarding the recording and 
reporting of dengue cases that are not good, inadequate clean water facilities and infrastructure, poor environmental sanitation, community awareness of dengue prevention efforts is very low and finally because Indonesia has a tropical climate makes it easier for mosquito vectors to be able to breed.

\section{Research Method}

This research is an analytic study using cross-sectional design. The study population was all families in Medan, the study sample as many as 300 families, taken using cluster sampling techniques. The data collection tool uses a questionnaire. Bivariate analysis using chi square test. This research was conducted in 2019. This study aims to analyze the relationship between the support of health workers and community leaders with the occurrence of dengue in Medan.

\section{Discussion}

The relationship between support of health workers and community leaders with the occurrence of dengue in Medan can be seen in the following table. The research results obtained were:

\subsection{Univariate Analysis}

Table 1. Frequency Distribution of Respondents according to DHF Occurrence

\begin{tabular}{clcc}
\hline No. & DHF Occurrence & Total & $\mathbf{0}$ \\
\hline 1 & Ever & 34 & 11.3 \\
2 & Never & 266 & 88.7 \\
\hline & Total & $\mathbf{3 0 0}$ & $\mathbf{1 0 0 , 0}$ \\
\hline
\end{tabular}

Based on Table 1 above, it is known that 34 respondents $(11.3 \%)$ stated that they themselves or one of their family members had been diagnosed with DHF during the past 6 months, and as many as 29 respondents $(9.7 \%)$ stated they had never DHF diagnosed.

Table 2. Frequency Distribution of Role of Health Workers

\begin{tabular}{clcc}
\hline No. & Health Workers Support & Total & $\%$ \\
\hline 1 & Good & 23 & 7.7 \\
2 & Bad & 277 & 92.3 \\
\hline & Total & $\mathbf{3 0 0}$ & $\mathbf{1 0 0 , 0}$ \\
\hline
\end{tabular}

Based on Table 2 it is known as many as 277 respondents $(92.3 \%)$ stated that the lack of support from health workers in preventing DHF occurrence and only 23 respondents $(7.7 \%)$ stated that the good support of health workers in preventing DHF. The results of interviews conducted by researchers with one of the health workers in the Medan Selayang Sub-district provided an argument that counseling and outreach activities about dengue were ever carried out in the field, however, when it arrived in the field because the majority of the population worked daily from morning to evening, the community was difficult found and if there is counseling done that comes only a few of the people in the environment. Health workers in the prevention of dengue fever have the responsibility of making home visits in this case to conduct counseling to the community, namely the family so that they understand and carry out prevention of dengue fever, do larvae checks in community homes, mobilize and oversee the eradication of nests mosquitoes and make reports on larvae examination results and report it every month (MOH RI, 2009). According to research Harahap (2012) that public health behavior in the prevention and eradication of mosquito larvae is strongly influenced by the role of health workers. 
Table 3. Frequency Distribution of Role of Community Leaders

\begin{tabular}{clcc}
\hline No. & $\begin{array}{l}\text { Community Leader } \\
\text { Support }\end{array}$ & Total & $\mathbf{\%}$ \\
\hline 1 & Good & 29 & 9.7 \\
2 & Bad & 271 & 90.3 \\
\hline & Total & $\mathbf{3 0 0}$ & $\mathbf{1 0 0 , 0}$ \\
\hline
\end{tabular}

Based on Table 3 above, it is known as many as 271 respondents (90.3\%) stated the lack of support from community leaders in preventing the occurrence of DHF and only 29 respondents $(9.7 \%)$ who stated there was or good support from community leaders for the prevention of DHF especially in Dissemination of information about DHF and efforts to overcome DHF event. The presence of community leaders (knowledge, attitudes and actions) will have a great influence on an individual on his health status, the role of encouragement from outside, the presence of role models or people who are emulated will determine how someone will behave or behave especially in efforts to prevent DHF. The results of interviews conducted by researchers with the community obtained information that community leaders rarely descend the environment to invite the community to participate in environmental hygiene activities in the dwelling even some people who claim there is no distribution of abate powder by local authorities and to obtain abate powder itself the community must buy it first.

\subsection{Bivariate Analysis}

Table 4. Relationship between Support of Health Workers and DHF Occurrence

\begin{tabular}{|c|c|c|c|c|c|c|c|}
\hline \multirow{3}{*}{$\begin{array}{l}\text { Health Workers } \\
\text { Support }\end{array}$} & \multicolumn{4}{|c|}{ DHF Occurrence } & \multirow{2}{*}{\multicolumn{2}{|c|}{ Total }} & \multirow{3}{*}{$p$} \\
\hline & \multicolumn{2}{|c|}{ Ever } & \multicolumn{2}{|c|}{ Never } & & & \\
\hline & $\mathrm{n}$ & $\%$ & $\mathrm{n}$ & $\%$ & $\mathrm{n}$ & $\%$ & \\
\hline $\mathrm{ad}$ & 31 & 11.2 & 246 & 88.8 & 277 & 100 & 0,734 \\
\hline Good & 3 & 13.0 & 20 & 87.0 & 23 & 100 & \\
\hline
\end{tabular}

Based on the table above, it can be seen that from the results of the answers of 277 respondents who stated that the support of health workers was not good in efforts to prevent DHF with the occurrence of DHF, there were 31 people $(10.3 \%)$ who had been diagnosed with DHF, while of 23 respondents who had stated the support of health workers both in efforts to prevent DHF with the occurrence of DHF, there were 3 people $(13.0 \%)$ who had been diagnosed with DHF. The results of the chi-square analysis $(p=0.734)$ showed that no significant relationship was found between the support of health workers and the occurrence of DHF.

Table 5. Relationship between Support of Community Leaders and DHF Occurrence

\begin{tabular}{|c|c|c|c|c|c|c|}
\hline \multirow{3}{*}{$\begin{array}{l}\text { Community } \\
\text { Leader Support }\end{array}$} & \multicolumn{4}{|c|}{ DHF Occurrence } & \multirow{2}{*}{\multicolumn{2}{|c|}{ Total }} \\
\hline & \multicolumn{2}{|c|}{ Ever } & \multicolumn{2}{|c|}{ Never } & & \\
\hline & $\mathrm{n}$ & $\%$ & $n$ & $\%$ & $n$ & $\%$ \\
\hline $\mathrm{Bad}$ & 31 & 10.3 & 240 & 82.0 & 271 & 100 \\
\hline Good & 3 & 1.0 & 26 & 80.3 & 29 & 100 \\
\hline
\end{tabular}


Based on Table 5 above, it can be seen that from the answers of 271 respondents who stated the support of community leaders was not good enough in efforts to prevent DHF with the occurrence of DHF there were 31 people $(10.3 \%)$ who had been diagnosed with DHF, while of 29 respondents which stated the support of community leaders both in efforts to prevent DHF with the occurrence of DHF, there were 3 people $(1.3 \%)$ who had been diagnosed with DHF. The results of the chi-square analysis $(p=1,000)$ showed that no significant relationship was found between the support of health workers and the occurrence of DHF.

\section{Conclusion}

From the above results it can be concluded that the role of health workers and community leaders was still lacking in efforts to prevent DHF. The presence of community leaders gives a great influence for an individual on their health status, the role of encouragement from outside, the presence of role models or people who are emulated will determine how someone will behave especially in efforts to prevent DHF. In the handling of DHF community participation is the initial key to the success of a health program, especially DHF prevention activities. The awareness of the community to know that they were willing and able to clean the environment where they live, participate in checking mosquito larvae and carry out three $\mathrm{M}$ activities (draining, closing, burying) will greatly affect the occurrence of DHF in the community. The existence of health workers greatly influences how one's health behavior, with the presence of health workers in a community environment, health information will be distributed to the community. It is hoped that this research can be used as material for information, input, and evaluation, especially for local government officials in making DHF prevention policies and increasing the role of the community in controlling DHF.

\section{References}

Ajzen, I., (2005). Attitudes, Personality and Behavior, 2nd Edition, McGraw-Hill Professional Publishing, Berkshire, GBR.

Aryati, I.C., Sali, I. W., \& Aryasih, I. A. (2014). Hubungan Pengetahuan Sikap dan Tindakan Masyarakat dengan Kejadian DBD di Kelurahan Baler Bale Agung Kecamatan Negara Tahun 2012. Jurnal Kesehatan Kingkungan , 4, 122.

Alidan, (2011), The Corelation of Knowledge, Attitude and Health Elucidation to the Dengue Hemorrhagic Fever (DHF) Mosquito Breeding Place Eradication in Subdistrict of Simpang III Sipin District of Kotabaru Jambi Municipality, Tesis: Universitas Gadjah Mada, Yogyakarta.

Anonim, (2011). Laporan Kasus Penyakit Demam Berdarah Dengue. Dinas Provinsi. Jawa Tengah. Semarang

Anonim, (2013a). Laporan Data Endemisitas Demam Berdarah Dengue. Dinas Kesehatan Banyumas. Banyumas.

Adik, et al., (2014). Kesehatan masyarakat di Indonesia konsep aplikasi dan tantangan. Raja Grafindo Persada: Depok.

Bakta, Kusuma, \& Bakta, I Made. (2014). Hubungan antara Pengetahuan dan Sikap terhadap Perilaku Pemberantasan Sarang Nyamuk (PSN) sebagai pencegahan DBD di Banjar Badung, Desa Melinggih, Wilayah Puskesmas Payangan.

DepKes RI., (2005). Penyelidikan Epidemiologis, Penanggulangan Fokus dan Penanggulangan Vektor Pada Kejadian Luar Biasa Demam Berdarah Dengue di Indonesia, Ditjen PPM \& PL, Jakarta.

DepKes RI., 2006. Pemberantasan Nyamuk Penular Demam Berdarah Dengue di Indonesia, Ditjen PPM \& PL, Jakarta. 
DepKes RI., 2007. Pemberantasan Sarang Nyamuk Demam Berdarah Dengue (PSN DBD) Oleh Juru Pemantau Jentik. Jakarta.

DepKes RI., 2010a. Profil Indonesia Sehat 2009. Jakarta

Depkes RI. 2009. Buku Pedoman Pemberantasan Penyakit Demam Berdarah. Jakarta : Ditjen PP\&PL. Jakarta.

DepKes RI., 2010b. Penemuan Tatalaksana dan Penderita Demam Berdarah Dengue. Jakarta: Dirjen P2L.

Dewi, N.P. (2015). Faktor-Faktor Yang Berhubungan Dengan Praktik Pemberantasan Sarang Nyamuk Demam Berdarah Dengue (Psn Dbd) Keluarga Di Kelurahan Mulyoharjo Kecamatan Jepara Kabupaten Jepara. Skripsi Jurusan Ilmu Kesehatan Masyarakat. Fakultas Ilmu Keolahragaan. Universitas Negeri Semarang https://journal.unnes.ac.id

Dinas Kesehatan Kota Medan., 2017. Data Kasus DBD 2017. Kota Medan.

Dinas Kesehatan Kota Medan., 2018. Data Kasus DBD 2018. Kota Medan.

Gay, L.R. and Diehl, P.L., 1992, Research Methods for Business and, Management, MacMillan Publishing Company, New York.

Green and Kreuter., 2005 Health Program Planning, An Educational and Ecological. Approach: Fourth Edition: ISBN: 007255683.8.Published By Mc-Graw-Hill 1121 Avenue of The Americans, New York.

Hardiyanti et al., 2011. Analisis perilaku masyarakat terhadap angka bebas jentik dan demam berdarah di Kecamatan Pekanbaru Kota Riau. Jurnal Ilmu Lingkungan. (5), hal 3.

Hartono, B. 2001. Promosi kesehatan: sejarah dan perkembangannya di Indonesia. Jakarta: Rineka Cipta.

Harahap, L., 2012. Hubungan pengetahuan, sikap, saran dan prasarana serta dukungan petugas kesehatan dengan pencegahan penyakit chikungunya mengunakan metode pemberantasan sarang nyamuk (PSN) oleh kepala keluarga di Wilayah Kerja Puskesmas Nurussalam Kabupaten Aceh Timur, Tesis S2, Medan: Universitas Sumatera Utara.

Hermansyah., 2012. Model manajemen demam berdarah dengue; suatu analisis spasial pasca tsunami di Wilayah Kota Banda Aceh. Disertasi Fakultas Kesehatan Masyarakat Universitas Indonesia. Jakarta.

Hidayah, A, (2009). Tingkat pengetahuan, sikap dan tindakan keluarga tentang pencegahan DBD Di Rw 09 Kelurahan Kramatpela kecamatan Kebayoran Baru Jakarta Selatan. Skripsi: Fakultas Kedokteran dan Ilmu Kesehatan Universitas Islam Negeri (UIN) Syarif Hidayatullah. Jakarta.

Hungu (2007). Demografi Kesehatan Indonesia. Jakarta: Grasindo.

Husna RN, Wahyuningsih NE, Dharminto. 2016. Hubungan Perilaku 3 M Plus dengan Kejadian Demam Berdarah Dengue (DBD) di Kota Semarang (Studi di Kota Semarang Wilayah Atas). Jurnal Kesehatan Masyarakat.Vol. 4 No.5:170-7.

Hutapea, B. 2007. Perilaku Masyarakat Mengenai DBD di kelurahan Gung Negari Kecamatan Kabanjahe Karo Tahun 2007. Fakultas Kesehatan Masyarakat Universitas Sumatera Utara.

Istiqomah, et al. (2017). Faktor-Faktor Yang Berhubungan Dengan Upaya Pencegahan Demam Berdarah Dengue (Dbd) Pada Ibu Rumah Tangga Di Kelurahan Kramas Kota Semarang. Jurnal Kesehatan Masyarakat, 5, 1.

Jane., 2012. Perilaku masyarakat tentang program pemberantasan penyakit DBD di Kabupaten Minahasa Utara. Skripsi Fakultas Kesehatan Masyarakat Universitas Sam Ratulangi, Manado.

Jata D, Putra NA, Pujastawa IGB. Hubungan Perilaku Masyarakat Dalam Pemberantasan Sarang Nyamuk dan Faktor Lingkungan dengan Kejadian Demem Berdarah Dengue di Wilayah Puskesmas I Denpasar Selatan dan Puskesmas I Denpasar Timur. Ecotrophic. 10(1), 2016. 
Kementrian Kesehatan RI., 2010. Demam Berdarah Dengue di Indonesia tahun 1968-2009. Buletin Jendela Epidemiologi. (2), Edisi. Hal 1-16 Agustus2010. Pusat Data dan Surveilens Epidemiologi. Jakarta.http://www.depkes.go.id/downloads/PROFIL_KESEHATAN_INDONESIA_ 2010.pdf (diakses: 9 maret 2019).

Kemenkes. (2011). Modul Pengendalian Demam Berdarah dengue. Kementrian Kesehatan Republik Indonesia Direktorat Jenderal Pengendalian Penyakit dan Penyehatan Lingkungan.

Kemenkes. (2016). Profil kesehatan Indonesia tahun 2015. Jakarta: Kementrian Kesehatan Republik Indonesia.

Khun S. \& Manderson, L. (2007). Community and school based health education for dengue control in rural Cambodia: A process evaluation. Plos NeglectedTropical Diseases, 1: 110.

Listyorini, P.I. (2016). Faktor-Faktor Yang Mempengaruhi Perilaku Pemberantasan Sarang Nyamuk (PSN) Pada Masyarakat Karangjati Kabupaten Blora. Jurnal Ilmiah Rekam Medis dan Informatika Kesehatan. Infokes, Volume 6 Nomer 1, Juli 2016.

Mardiana, 2010. Panduan lembaga lengkap kesehatan mengenal mencegah dan mengobati penularan penyakit dari infeksi. Yogjakarta: Citra Pustaka.

Marini, D. 2009. Gambaran Pengetahuan, Sikap dan Tindakan mengenai DBD pada keluarga di Kelurahan Padang Bulan tahun 2009. Fakultas Kedokteran Universitas Sumatera Utara.Medan.

Meliala AM. Sisi lain dari Kejadian Luar Biasa (KLB) Demam Berdarah Dengue. Journal data dan informasi kesehatan. Jakarta: Depkes RI. 2004. 4. hal. 55-59.

Najmah, 2016. Epidemiologi penyakit menular. Jakarta: Trans Info Media.

Notoatmodjo, 2003. Pendidikan dan perilaku kesehatan. Jakarta: Rineka Cipta.

Santoso, Budiyanto A. 2008. Hubungan Pengetahuan Sikap dan Perilaku (PSP) Masyarakat terhadap Vektor DBD di Kota Palembang Provinsi Sumatera Selatan. Jurnal Ekologi Kesehatan. Vol.7,No.2 .Hal 732 7739

Sarwono, Solita. 2007. Sosiologi kesehatan: beberapa konsep beserta aplikasinya. Yogyakarta: Gadjah Mada University Press.

Sitio A., 2008. Hubungan perilaku tentang pemberantasan sarang nyamuk dan kebiasaan keluarga dengan kejadian demam berdarah dengue di Kecamatan Medan Perjuangan Kota Medan Tahun 2008. Tesis: Program Pasca Sarjana Universitas Diponegoro Semarang (diakses: 9 Maret 2019). http:/ / eprints.undip.ac.id/16497/ANTON SITIO.pdf

Soedarmo. 2010. Buku ajar infeksi dan pediatri tropis (second ed) Jakarta: Ikatan Dokter Anak Indonesia.

WHO. (2016). Weekly epidemiological record. World Health Organization, 350. 